Nehring, K., R. Schiemann, L. Hoffmann \& W. Klippel, 1960. Die Verwertung der Futterenergie in Abhängigkeit von Ernährungsniveau. Versuche mit Schweinen. Archiv für Tierernährung 10: 275320.

Norfeldt, S., A. Ruudvere, E. Toiger \& P. Lagerwall, 1954. Digestibility experiments with pigs. Kungliga Lantbrukshögkolans Annaler 21: 1-29.

Parker, J. W. \& A. J. Clawson, 1967. Influence of level of total feed intake on digestibility, rate of passage and energetic efficiency of reproduction in swine. Journal of Animal Science 26: 485-489.

Petry, H. \& H. Enders, 1974. Kritische Betrachtungen über die Zuverlassigkeit der im klassischen Verdauungsversuch und nach der Chromoxid-Indikatormethode bestimmten Verdauungskoeffizienten. Zeitschrift für Tierphysiologie, Tierernährung und Futtermittelkunde 33: 88-98.

This synopsis is based on a report by G. Oude Elferink, A. Mentink, H. Everts, B. Smits \& $A$. W. Jongbloed, entitled 'Digestibility in swine depending on several factors: literature research and report of a number of trials', Report IVVO No 174, Institute for Livestock Feeding and Nutrition Research, Lelystad, 1986. 81 pp., 10 figs., 39 tables, 79 refs., 6 appendices.

Available as paper copy (order R060P, $f 20$ including postage) or microfiche (order R060M, $f 12.50$ including postage) at: NARD, clo Pudoc, P.O. Box 4, 6700 AA Wageningen, Netherlands (telex 45015 blhwg nl).

\title{
Influence of potassium fertilizer on yield of upland kangkong (Ipomoea aquatica Forsk.)
}

A. R. Linnemann, S. Hitipeuw, B. Kruiger and E. Westphal (Department of Tropical Crop Science, Agricultural University, P.O. Box 341, 6700 AH Wageningen, Netherlands)

Received 4 September 1986; accepted 24 September 1986

\begin{abstract}
In a greenhouse experiment, effects of potassium fertilization on yield and potassium content of kangkong (Ipomoea aquatica Forsk.) were investigated. Kangkong was either ratooned (ratoon method) or resown after harvesting whole plants (seed method).
\end{abstract}

Key words: kangkong, Ipomoea aquatica, leaf vegetable, potassium fertilization, yield, ratoon method.

Introduction. Kangkong, a popular leaf vegetable in Southeast Asia, has received little research attention. Information on effects of cultural practices, among which manuring, on quality and yield of kangkong is limited (Cornelis et al., 1985). In a 
greenhouse experiment, carried out in the Netherlands, application of nitrogen gave higher yields, but also higher nitrate contents (Linnemann et al., 1986). The present study focussed on the effects of potassium fertilizer on yield of kangkong.

Material and method. The trial with upland kangkong cv. Large Leaf of the Known You Seed Company, Taiwan, was carried out in 1983 in a greenhouse of the Agricultural University at Swifterbant, the Netherlands. The soil mixture consisted of equal volumes of sand and peat. To this soil was applied: $\mathrm{N} 250 \mathrm{~kg} \mathrm{ha}^{-1}$ as ammonium nitrate limestone $\left(\mathrm{NH}_{4} \mathrm{NO}_{3}+\mathrm{CaCO}_{3}, 26 \% \mathrm{~N}\right) ; \mathrm{P}_{2} \mathrm{O}_{5} 150 \mathrm{~kg} \mathrm{ha}^{-1}$ as triple superphosphate $\left(46 \% \mathrm{P}_{2} \mathrm{O}_{5}\right)$ and $\mathrm{Mg} 15 \mathrm{~kg} \mathrm{ha}^{-1}$ as magnesium sulphate $\left(\mathrm{MgSO}_{4} \cdot 7 \mathrm{H}_{2} \mathrm{O}\right.$, $15 \% \mathrm{MgO}$ ). Three levels of potassium fertilization were tested. In total, rates of $\mathrm{K}_{2} \mathrm{O}$ were 100,250 and $400 \mathrm{~kg} \mathrm{ha}^{-1}$ over the experimental period of 12 weeks. These amounts were applied as sulphate of potash $\left(48 \% \mathrm{~K}_{2} \mathrm{O}\right)$ in four equal portions with intervals of three weeks, the first dose just before sowing.

Square planting at $10 \mathrm{~cm}$ gave a density of 100 per $\mathrm{m}^{2}$. The crop was harvested either by ratooning (cutting plants $\mathrm{ca} 5 \mathrm{~cm}$ above soil surface) or by taking whole plants (cutting at ca $5 \mathrm{~cm}$ and uprooting the stubble) and resowing the cleared plots, here referred to as 'seed method'. At harvest, plants were weighed fresh and dry, and the number of stems per plant and leaves per stem were calculated. $\mathrm{K}$ analysis was performed at the Department of Soil Science and Plant Nutrition of the Agricultural University, Wageningen. After the last harvest, soil samples were analysed for their potassium content after extraction with $\mathrm{HCl} 0.1 \mathrm{~mol} \mathrm{l}^{-1}$. The computer package 'Genstat' was used for statistical analysis.

Results. The first harvest was at a crop height of $30 \mathrm{~cm}$, five weeks after sowing. With the seed method, a second crop could be obtained within the trial period. However, by ratooning three crops were harvested, resulting in a considerably higher yield. Differences in total yield were not significant for potassium rates (Fig. 1). Average dry matter content was also not significantly influenced by potassium rates, nor were the mass rations of leaves to stems, the number stems per plant, the number of leaves per plant, or the number of leaves per stem.

Average potassium content of leaf-blades and of stems plus petioles was significantly influenced by potassium rates at both cropping methods. For the ratoon crop the average potassium content in dry matter increased from $770 \mathrm{mmol} \mathrm{kg}^{-1}$ at the lowest fertilization level to $1530 \mathrm{mmol} \mathrm{kg} \mathrm{kg}^{-1}$ at the highest level. With the seed method, an increase was found from $825 \mathrm{mmol} \mathrm{kg}^{-1}$ at the lowest level to $1440 \mathrm{mmol}$ $\mathrm{kg}^{-1}$ at the highest level. The potassium content of stems plus petioles was more than twice as high as the potassium content of leaf-blades.

Conclusions. Of the plant characteristics measured, potassium rates did not have a significant effect on yield components of kangkong, but only on the potassium content of the plant material. Higher potassium rates gave higher contents in stems and leaves. Potassium contents of stems plus petioles were more than twice as high as the contents of leaf-blades. Hence, the increase in potassium contents of plant ma- 


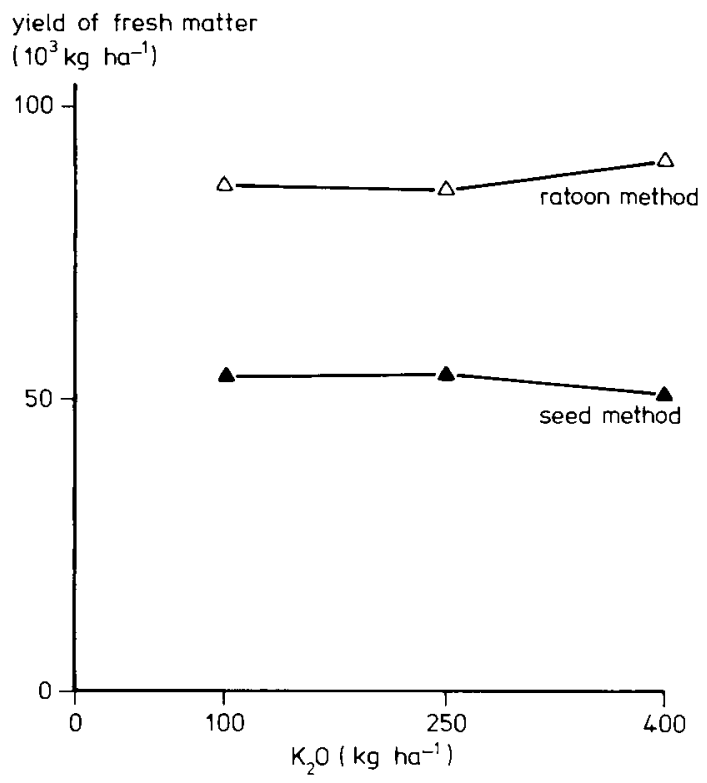

Fig. 1. Yield of fresh matter $\left(10^{3} \mathrm{~kg} \mathrm{ha}^{-1}\right)$ for potassium rates $\left(\mathrm{kg} \mathrm{ha}^{-1}\right)$ after 9 weeks for the seed method and after 12 weeks for the ratoon method.

terial at potassium rates above $100 \mathrm{~kg} \mathrm{ha}^{-1}$ were so-called luxury consumption by the kangkong plants.

\section{References}

Cornelis, J., J. A. Nugteren \& E. Westphal, 1985. Kangkong (Ipomoea aquatica Forsk.): an important leaf vegetable in Southeast Asia. Abstracts on Tropical Agriculture 10 (4): 9-21.

Linnemann, A. R., J. M. Louwen, G. H. M. B. Straver \& E. Westphal, 1986. Influence of nitrogen on sown and ratooned upland kangkong (Ipomoea aquatica Forsk.) at two planting densities. Netherlands Journal of Agricultural Science 34: 15-23.

This synopsis is based on a report by the same authors entitled 'Influence of potassium fertilizer and plant density on yield components of sown and ratooned upland kangkong (Ipomoea aquatica Forsk.)'. Department of Tropical Crop Science, Agricultural University, Wageningen, 1986. 8 pp., 4 figs., 2 tables, 3 refs.

Available as paper copy (order R061P, $f 20$ including postage) or microfiche (order R061M, $f 12.50$ including postage) at: NARD, clo Pudoc, P.O. Box 4, $6700 \mathrm{AA}$ Wageningen, Netherlands (telex $45015 \mathrm{blhwg} \mathrm{hl}$ ). 